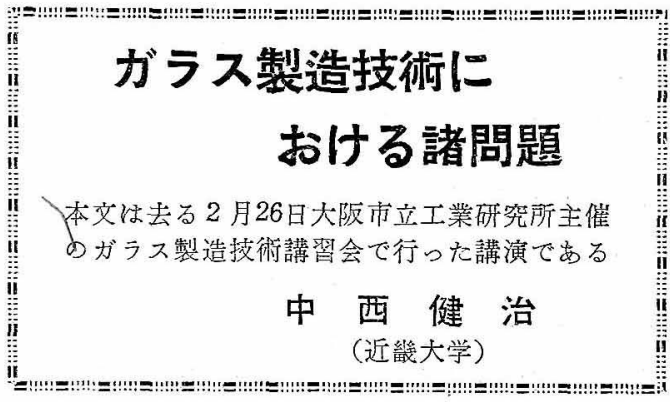

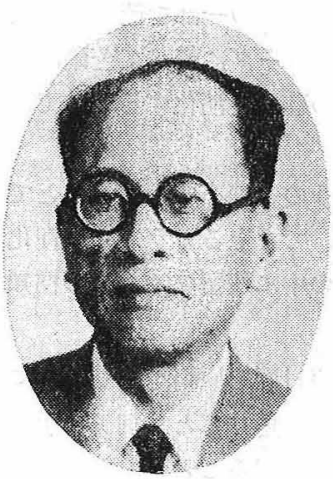

写真沙著者近影

\section{緒 咅}

ガラスは工業材料の中 で特化重要な役割をし て䅂り，セメント，ゴム 鉄などとならんで，今日 までの物質文明の花形で あったが，最近プラスチ ックが新しい工莱材料と して登場し，ガラスの領 域の中にも侵入して来た ので，ガラスの活動舞台

が狭まろうとしているととは事実である。

試艾に次表を参照されたい。

\section{ガラス製品一覧表}

建筑用品＼cjkstart㥶ガラス，板ガラス，タイル，ステン ドガラス, ガラス棟瓦, 多泡ガラス

日用品食器, 容器類, 電灯笠, 電球, 卓上置 物類, 時計がラス, 鏡, 塈法瓶, アン プル，注射筒，眼镜

鉄㣀, 航空 信号用レンズ, 照明器反射鏡濾光がラ 船船用品 ス,ゲージガラス，ガラス綿

理科学用品 寒暖計ガラス, 各種研究用器具, 光学 用ガラス, 電極, カバーガラス

電気用品碍子, 真空管類, 螢光灯管, レントゲ ン隩断板, 計器カバー

漁業用品 浮玉

工望 品 模造宝石, 光珠, 模造真珠, 釦, ダィ ヤ粉，人形類，ねり吅の，マーブル玉 腕輪, 義眼

その他 人絹工業用品, ガラスタンク，ホャ， 油壸

表中，ゴジック体愣在既に盛えにプラスチック で作られているもので，アンダーラインは䓵作また は少量作られているるのである。

すなわち，プラスチックはあらゆる部門でガラス代 用品として進出し，「ガラスより西優秀である」とい わんばかりの勢を示している。プラステックは今後ま だまだ種類も增えようし，質も良くなるうから，ガラ

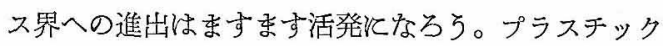
がこのように媣くガラスの領域侵入して来たのは， これが元来ガラスに良く似た性質があるからである。 透明で，着色が自由な点などはガラスと全く同じであ る。軽くまたやわらかく切断，穿孔が非常に容易な点 は，一面ガラスに優った性質とも言える。乙かし，ガ ラスに較べて劣っている点も多々ある。硬度がガラス の約半分で，キズがつき易く，化学的にもガラスより

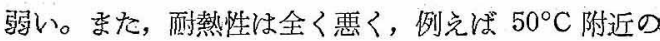
熱水長く漬けて和くと表面が量り，また水分も吸収 する。150 ${ }^{\circ} \mathrm{C}$ 附近飞熱すると悪莫を放ち，長時間にわ たると中気泡が現われてくる。すなわち，分解を始 めるのである。250年 以上になる炭化する。インク や染料に染まり,コーヒーによって子污染する。他の 有機物やバクテリアを吸着しなかなか洗い落せない。 つまり現在大采徂伝しているプラスチックの食器は 非衛生的で：はなはだ感心しないのでする。製造コス トはガラスの 2 〜倍も高い。

このようと見てくると，ガラスとしては，プラスチ ックに優る性質を多分飞持っているのであるから，と の性質を十分発揮させて，その活躥領域を確保すると 同時に，さらに新しい性質のるのを作って用途を抬張 して行けげ，准む道はいくらであめるわけである。

しかし，それそはまず第一沉現在のガラス工場の作 業なり設倩なりを合理化して，新しい時代にふさわて い形態としなければならない。

現在, わが国のガラス製品で最も検討を要するのは 生地である，ガラスを使う場合飞素地の質が悪いため 飞，止むを得ず他の材料を選ぶ場合が少なくない，す なわち，ガラス工業の繁栄策は素地の向上から，そい うことになる。

\section{1. ガラスの組成}

ガラス素地の性質に最も大きく影響するのはと組 成である。したがって組成と性質の関係については昔 から多くの人が研究し，一応基礎はできているのでま るが，ガラスの製造設備とか，加工の熟練度とかいう いろいろの事情で，工場々必ずしも基憷方式通りの組 成のガラスを作らないし，また一面ガラスを使う側の 注文条件が年ふ苛酷になってくるので従来の組成のガ ラスでは用をなさなくなっている場合もあり，ここに ガラス組成の検討索必要とするよう店ってきている のである。

現在ガラスの性質に詨する要求とか，不平とかいる ものはいるいらあるが, そのらちの一つ理科学用ガ ラスがある。現在入手する科学研究室用ガラス器の大 半は化学的に不良で, 精密を要する実験には使えな い。水，酸，アルカリに抵抗性が極めて弱いね゙かりで 
なく油脂や樹脂中の極く微弱な酸にもいちぢるしく侵 される。それ故研究室ではプラスチック, 銀, ニッケ ルなぞを使い分ける方が，ガラス器を使うよりはるか て安全であるとさ光言われている。これなどは最子手 近かな研究課題の一つである。ボイラーのゲージガラ スはボイラー圧がますます高くなり，通常40気圧（ア， メリカは 50 気圧のものが珍しくなく, 特殊のものは 105 気圧と云われる）になっているので 10 年前の30 気圧程度の時代に較べればゲージガラスの腐蝕は比較 てならぬ程激しくなっている。したがってゲージガラ ス組成は全く新しい考方方によって作られなければな らない。もちろん，言うまでもなくこのような苛烈な 用途に対しては，プラスチックに進出の余地は全然な くガラスの独り舞台と言えよう。レインフォーストプ ラステックの骨骼にされるガラス繊維には強度が重要 な性質とされるが，これて対する研究すまだ完壁では ない。また写真器用光学ガラスの組成と光学恒数関 する研究は現在日進月歩の勢いであるが，レンズ設計 家が次から次と新要求を出して来て, 絶刘に「もうよ い」とは言わない。苦しいが将来性のある部門で离 る。プラスチックである種のレンズやプリズムができ ているが, 元来プラスチックの光学恒数はガラスのよ 万反広い範囲飞変化していないから, その光学界への 進出は大して恐れるにも当ら奴らう。空ガラスや板 ガラスの組成は長年の研究や経験とよって大体決って いるが，それとるかかわらず，まだまだ研究の余地が める。何となれば工場は絶えず失透問題苦しめられ 焼けやソーラリゼーションの問題に悩をされているか らである。その上製造能率を上げるためのガラス生地 の粘度や作業温度範囲付する竩成の影響はも万少し 突込んで研究しなければならない。

かく挙げてくると, 組成汇関して研究を要する部門 は非常に広く，ころいう方面を進めて行けばプラスチ ックなどの拉よびもつか特殊な性質を作り出せるは ずである。

いホ,ソーラリゼーションのととに一寸触れたが， これは空，板ガラスのみならず一般ガラス器具でも問 題となることである。作り立ての時は清新な淡青色を 帯びていたガラスが，時日を経るにしたがって污黄緑 色飞変化する現象である。空ガラスの1枚が割れて新 しい空板を入れると，他の部分の空は活ない黄緑色で あるところへ, 新しい淡青色の空ガラスを入れたの

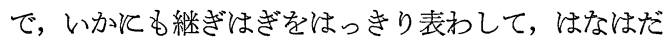
不体裁な外観となる。酒摆その他鉄の青色の比較的濃 いガラス製品にはすべてこの現象が現われる。時とは 製造工場飞ストック中に色が変り, 商品価值が低下し て売りマくくなる例がしばしばある。このソーラリゼ ーションは鉄の青色の濃いガラスと起るが，その原因
はガラス中の鉄の酸化でめって，バッチに亜砒酸を多 量含む時特飞現われ易く, またガラス愹融を不十分に 行った時にも起り易い。

いままで述べたのはガラスの化学組成のことである が，バッチの原料の検討がやはり大切である。何とな れば，化学組成は同一でも，バッチの原料が異なると 熔融の時の様子も違うし, でき上るガラスの性質も違 ろことがあるからである。タンク熔融の際に, ソーダ 原料としてソーダ灰だけを用いると，てかく砂利（不 熔融珪砂）ができ易いが，ソーダの一部を芒硝で置換 すると砂利の出現を防げる。ソーダに較べて艺硝は珪 秒との反応が遅れ，未消化の理砂を消化するからであ る。

石灰原料《炭酸石灰を使うのと消石灰を使うのとで はガラスの愹け方も違うし，でき上るガラスの物理化 学的性質も異なる。ガラスの中残留するガスの種類 や量が違うためらしい。

ガラスを製造する場合，毎日同じ原料を同じように 調合しているともかかわらず，愹け方とか細工の手応 党が非常に変り，さんざん手古摺ることがある。しか も其の原因が解らぬらちとまたいつの間にかると通り そか觉る。原因として，原料の水分含有量や不純物等 の変動, 石炭発熱量の低下, 煙道の閉塞なぞいろいる の場合があるが，特に原料の水分とか不純分の変動に は不断飞注意しなければならない。石炭は眝炭中にぞ えぞんカロリーが低下することは判って物りながら対 策らしいことが考光られないのが一般である。自然発 火の危険とカロリー減少の度合を汇らみ合わせて貯蔵 の際適当に隠蔽処置をすべきである。

ガラスの吹製を人工で行う場合には，ガラスに粘度 の変化が起ってもある程度手加減で作業の調節ができ るのでペケ品を出さずとすむ。しかし，全自動機械に よる吹製の場合は，手細工ほどデリケートな調節がで きないから，たちまちぺケ品の山を作る。自動機で製 造コストを下げる筈のものが実際は反対の結果とな る。タンクの作業室の素地または（坩倜突の場合は） 各坩堝内の素地は常飞一定の粘度, 作業性 (Working property）を保持すべきで，その.ためねはバッチつ組 成は厳格に不変でなければならない。

調合されたバッチの組成と変動がなくても，これを 運搬する時飞成分が分離 (Segregation)することが ある。また，炉江投入する際江成分中刀ある物が飛散 することもある。こうなると折角つバッチすだいなし である。一般汪，バッチつ中で珠秒とか石粉は石灰や ドロマイトレ較べると粒子が大きく重いので容器つ底 そ沈み，上層は石灰やドロマイトに富んだものになる そのようなバッチを炬没入すると愹融の進行が不整 そなり，良い素地ができない。大形のバッチビンを使 
用する場合などこの不都合はしばしば起る。バッチ 中, 石质やドロマイトは比較的飛散し易く, 飛散粉鹿 の $50 \%$ 以上は石灰, ドロマイトである。るし, 飛散 量が多い場合にはバッデ成分飞相当大きな変化を与兄 ることを念頭就くべきである。

\section{2. 熔融}

バッチを愹融する場合に，タンクにするか䏴堝とす るか柱, 製品の種類, 品質, 量, 燃料の種類などを勘 案して決めるわけであるが，もし然料江重油かガスが 使えるならば，できるだけタンク㛑融を採用すべきで ある。1 種類のガラスを 1 日 3 トン以上熔かすのに塻 堝を使うのは製造コストの点から言っても, 手間から 言っても全く不利でめる。データンクの研究は余り熱 心行われていないが，中小工場で製品の品質を良く し，しかもコストを下げる第一の方法はデータンクの 使用にあると言っても過言ではない。

大形の連続作業のタンクの操業は実とむずかしい。 作業室に, 作業に適当した素地が流れてくるようにす るには,タンク内の素地の流れを適正にしなければな らないが，この素地の流れは一つにかかってタンク内 のガラスの温度分布にある。しかし，タンク内のガラ スの温度分布を直接知ることはできないから, 作業員 は帅の内壁または内壁に近い部分の温度を測定し, 間 接に素地の温度分布の調節をする。注意すべきは炻内

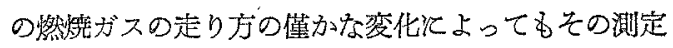
温度が変動することである。実際のととろタンク作業 は経験瀬らざるを得ない。フォームラインの位置や 形によってタンク㩭業の調節の目安とすることは最も 普通汇行われているが，艺れは他のデータ，例えば一

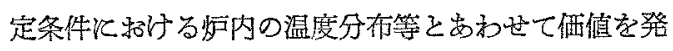
揮するるのであって，このもの単独で㩧業の目安とす るのは危険である。

タンクを外部から空気冷却することは重要である が，炬の部分によって冷却の程度を加減すべきで，一 律に全力を挙げて冷やすようなやり方は害てそあれ益 はない。これはタンク内の素地の流れを混乱させる原 因を作る。

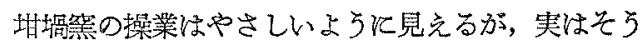
でない。绉の吹出孔の大きさ, 形状 (孔の下部の㛐瓦 の積み分），塔堝との間隔，全坩堝の妒內占める容 積などは，熱の效き方に非常に影響する。叶堝の寿命 はその空焚きの温度や時間によってはっきり影響を受 ける。寿命の長い坩坦は必らずガラス飞侵蝕される程 度も少ないから，したがって，ガラスの引上率もよく なり，いわゆる底素地まで使えるようとなる。これら のととはたちまち生産コスト響いてくる。

㙋培等に石炭を使うか重油を使うかは，現在わが国一
のガラス工場の一つの研究課題である。大体カロリ一 当りの值段は等しいが, 最初の設㣁費は重油も決して 安くない。ポンプ,タンク, バーナー, 配管工事等の

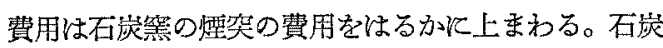
焚きの場合の自動給炭装置等の費用などを考克, 最初 の設備費は大体似たすのとして, さて操業に入った後 を考学ると，重油はなるほど操作は容易であり，人件 費す石炭焚きの場合より少なくてすむが，これが輸入 品であるといら点で常住国際経済涼響されるので企 業の安定性が危ぶまれる。石炭もス卜等の事情で時に は企業家を泣かすことはあるが，これは国内で解決で きる問題であるから重油程深刻でない。最近起っ ている重油輸入制限の話題は，業者を極度て憂榃に追 い込んでいる。このようなととを考光ると，重油を礼 譛するより洗寧る石炭焚きを選びたい。

\section{3. 金 型}

現在一般に使用されている金型は鋳鉄製である。鋳 鉄は無数のピンホールを含有しているので，いくら入

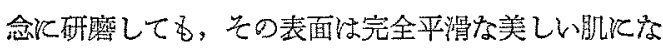
らない。それを押し型使用するとガラス肌はアバタ 面になり光沢が悪い。腼し吹きの揚合は押し型程では ないが，しかしやはり肌は十分きれいではない。か も，乙の金型は使用するにしたがってガラスのために 侵され，表面が荒れてきてますます製品の肌が悪くな る。

ガラス製品の良否判定の一つの規準は肌の良否であ るから，とのような型を用いたのでは最優秀というよ うな品物のできないのは当然である。苩から，日本製 品がチェッコとかフランスとかいう国の製品より見劣 りのする最大原因肌の不良在ったが，それが皆こ の金型の材質によって起っているのである。それだか らガラス金型用金属の研究は一日も早く行わねばなら ない問題である。

最近アメリカで発明されたミーハナイトという合金 はガラス金型用として注目をひいている。これは従来

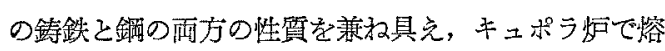
かして任意の形に鋳造ができ，乙か子鉦のように非常 飞緻密な組織它有している。12種類のるのがあって， その中に酸化作用水対して酎久性の強いるのがあ る。外国の試験例ではガラス墤型として優秀な成績を 示したと言われているので, わが国でも早急に試験す べきものであろう。この外，ノシュラとか，またわが 国で作られている共有黒鉛鋳鉄などルついても試験す る必要がある。要すると1日も早くスッキりした製品 を柞って，大い《海外輸出の成績を挙げたいるのであ る。プラスチックは透明性はあっても，との表面の光 沢法ガラスに遠く就よばない。もしも，ガラス製品つ 
肌が現在よりもさらに美しくなれば，それだけでもプ ラステックの進出を防げるのである。

\section{4. 職場の環境}

従業員つ作業能率は環境化よって非常に左右され る。ガラス工場は熱いのは当り前であるが，てれる換 気設倩の良否によって体へのコタエ方が違う。それ に，バッチの成分や燃料からくる西硫酸ガスの刺激臭 がある場合には，換気問題は非常に重大になってく る。亜硫酸ガスは空気 $1 l$ 中《 $0.03 \mathrm{mg}$ 附近めって る呼吸器を害し，また屒期間呼吸すると肝臟を侵して 白血球の激隇を来す。明腺飞刺激臭のある場合は 0.3 mg 以上あるのであって, その場合は短時間の呼吸で

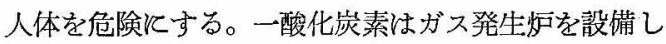

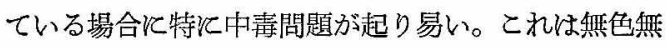
泉なるが故に災害が非常に頻繁である。工場の換気設
備は屋外の風向きの如何飞かかわらず有效々働らくよ うそして置かなどれば甲斐がない。

\section{緒訔}

ガラス製品はプラスチックのためと大分との領域が 侵されて来て，この工業えのものの前途までがはなは だ心細く感ぜられる。しかし,ガラスの特徴を発揮させ ると共䏓，新しい性質のガラスを作ってプラスチック の追従を許さない方面進出すれぼ，心細いどころか 前途は洋々たるものである。ガラスの性質の向上とか 新しい性質のガラスの製造とかいうととに対しては， その組成, 原料, 熔融法等, ガラス素材の作り方関 するもろるろの事柄の総合的研究が必要である。ガラ ス工業を今日の新しい時代に適合したるのたらしめる には, どうしてもこれらの点の研究を一段と進めなけ ればならない。

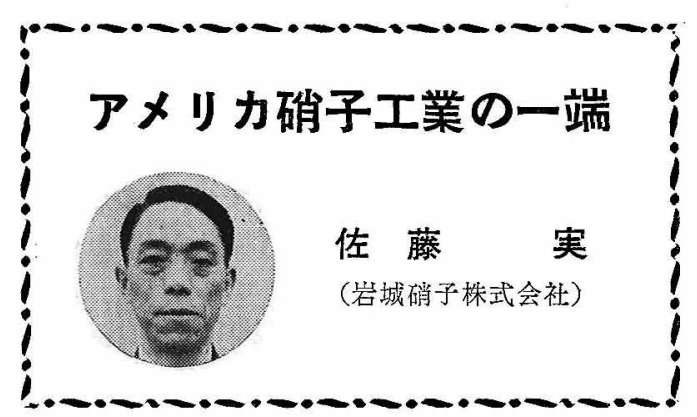

僅か 2 ケ月たらずの外遊期間中，1 1 月をコーニン グでテレビジョン用ブラウン管球の製造技術習得過 したので，各地を廻る余裕もなかったが，アメリカの 硝子工業の一端炍ついて所感を哒べる。

ニューヨークK足を止めた旅行者が必ず一度は見物 に行く一つ国連の建物がある。雪雲に括括われた 1 月終りの空に異様な形でそび兄ているとの建物の前 を，驚異の目を見張って見上げては歩き，止っては見 上げ，寒いのに屋内に入ろうともせず，長い周囲を歩 いて行く日本人がある。何を驚き何を考光ているので あらうか。日本で私たちね熱線吸収硝子の小さな防熱 フィルターを作るのに，泡があるとないとか，眽理が めるとか種々の問題を残している。それなのと，この 建物は $6 \times 12$ 尺以上も岕ると思光る熱線吸収硝子の穈 き板硝子で数十階つ全面を張りめぐらされてある。周 辺の建物の一部は大理石を薄く板状にしたような感じ の半透明のホトセンシチブ硝子の板で張られてある。 硝子関心をるつ者が，ただこれだけの硝子を見ただ けで何事を感じるだるらか。
低空飛行で，高層建築の林立する空の照明の光りと 織りなすネオンの形と色が入乱れて不夜城そ誇るニュ 一ヨークの夜景を見ると，正坐の偉観と云いたく なる。照明のある所必ず硝子が使われているわけで， 物凄く大きな板硝子を使ったショーウインドウや，強 化硝子のドアー，バー，レストラントのきれいな硝子 器類やテレビ，スコッチライトの広告等々。この光景 を見て，アメリカでは如何多くの硝子が，をた量的 飞交明生活飞役立っているかを確認するというのも今 さら物かしいが，そう云わざるを得ない。アメリカの 家庭生活を例取っても日本とは比較になら硝子製 品が大量汇使用消耗されている。すなわち，自動車あ りテレビ, ラデオめり, パイレックス食器類, 各喠墂 詰食料, 飲料, 各種コップ類, 装飾器等々生活様式が そうさせることになる。

アメリカの生活水準は世界中で群を抜いて高く, 日 本飞比較して 15 倍強, この膨大な経済力の基盤の上 そアメリカの各種工業は発展して来たので岕って, 硝 子工業も同様他工業と共にここ 30 40 年に警異的 発展をしたのである。アメリカ国民の進歩性と努力は

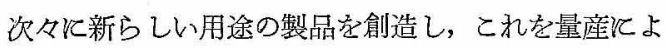

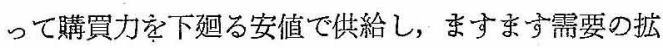
大を計り，設備の改良生産の增強を実施して来たので ある。アメリカの硝子工業が以上のよう惠まれた条 件下発展して来它とは云党, これ従事した経営者 はもちろ九，技術者の根強い研究飞創造性とたくまし い実行力を見逃してはならない。

ニューヨークのホボケン停車場からラカワンナ鉄道 